Tyndale Bulletin 71.2 (2020) 253-279

\title{
THE TYPOLOGICAL EXPECTATION OF PSALM 68 AND ITS APPLICATION IN EPHESIANS 4:81
}

\author{
Joshua M. Greever \\ (joshuagreever@gmail.com)
}

\begin{abstract}
Summary
Paul's use of Psalm 68:18 in Ephesians 4:8 has historically been a crux interpretum for New Testament hermeneutics and Pauline scholars alike, for Paul appears to misapply the features of the psalm to Christ. In light of recent scholarship, this paper argues that Paul's apparent misapplication of the psalm is resolved by a proper recognition of the psalm's typological framework. Paul applied Psalm 68:18 to Christ in light of the psalm's typological expectation and its redemptive-historical fulfilment in Christ. The psalm's typological indicators are evident in view of its retrospective and prospective orientation and the probable allusions to Exodus 15 and Judges 5. YHWH's ascension, captives, and gifts in Psalm 68:18 correspond to and anticipate a greater ascension, captives, and gifts. The eschatological interpretation of the psalm explains its use in Ephesians 4:7-16, for it sheds light on the unusual appearance of $\delta$ io introducing the citation, the textual modifications Paul introduced to the citation, Paul's choice of Psalm 68:18 in particular, and Paul's emphasis on ministers of the word in Ephesians 4:11-16. This analysis absolves Paul from the charge of hermeneutical insensitivity and aptly illustrates his hermeneutical approach to the Old Testament Scriptures.
\end{abstract}

1 This is a revised version of a paper presented on 20 November 2019 at the Annual Meeting of the Evangelical Theological Society in San Diego, California. 


\section{Stating the Problem}

Paul's use of Psalm 68:18 in Ephesians 4:8 has historically been a crux interpretum both for New Testament use of the Old Testament and, more generally, for one's hermeneutical approach to the Scriptures. ${ }^{3}$ Not only is Psalm 68 in its own right "considered with justice as the most difficult of all the Psalms', ${ }^{4}$ but also Paul's use of Psalm 68:18 in Ephesians 4:8 has been a proverbial thorn in the side of Ephesians scholars. One commentator has noted of Ephesians 4:8 that 'This and the next two verses of Ephesians are possibly the most difficult in the whole letter.' ${ }^{5}$

The chief difficulty lies in Paul's apparent misuse or misapplication of Psalm 68:18. Psalm 68, which speaks of YHWH's ascension of Mount Zion, does not appear to refer to Jesus's ascension to heaven. In the psalm, the captives YHWH leads in tow probably refer to human enemies from the conquered nations, whereas in Ephesians 4:8 they are likely evil principalities and powers. Further, the gifts in Psalm 68:18 are either tribute from the conquered nations or glad-hearted gifts of devotion from Israel, whereas in Ephesians 4:8 they are gracious gifts from Christ, namely, ministers of God's word (Eph. 4:11). At every step of the way ascension, captives, and gifts - Paul appears to misapply the features of the psalm to Christ and the Ephesians. ${ }^{6}$

There have been numerous solutions suggested in the history of interpretation. ${ }^{7}$ On the one hand, some interpreters contend that Paul quoted a different text-form from that which appears in the Masoretic Text or Septuagint. ${ }^{8}$ On the other hand, some argue that Paul quoted

2 Unless otherwise noted, I will utilise the English versification (Ps. 68:18), not that of the MT (Ps. 68:19) or LXX (Ps. 67:19). Also, unless otherwise noted, all translations are those of the author.

3 Pauline authorship of Ephesians is debated. Although I am convinced of Pauline authorship, this in no way determines my thesis, inasmuch as my focus is on the author's use of Ps. 68:18 within Ephesians itself, without regard to other Pauline letters. In keeping with the letter's own claim, I will use the name 'Paul' to refer to the author of the letter.

4 W. F. Albright, 'A Catalogue of Early Hebrew Lyric Poems (Psalm 68)', HUCA 23.1 (1950): 7. Similarly Marvin E. Tate, Psalms 51-100 (WBC, 20; Dallas: Word, 1990): 170: 'The difficulties of interpreting Ps 68 are almost legendary.'

5 John Muddiman, The Epistle to the Ephesians (BNTC; Peabody: Hendrickson, 2001): 187.

6 Hans-Joachim Kraus, Psalms 60-150: A Continental Commentary (Minneapolis: Fortress, 1989; tr. from German, 1978): 56 baldly states that the author of Ephesians 'wrongly applied' Ps. 68:18.

7 For a good survey of the recent history of interpretation, see Seth M. Ehorn, 'The Use of Psalm 68(67).19 in Ephesians 4.8: A History of Research', CBR 12 (2013): 96-120.

8 E.g. Richard Rubinkiewicz, 'Ps LXVIII (= Eph IV 8): Another Textual Tradition or Targum?', NovT 17 (1975): 219-24; Richard A. Taylor, 'The Use of Psalm 68:18 in 
Psalm 68:18 in substance but revised it in light of the whole psalm or redemptive history. ${ }^{9}$ This latter interpretation, which has recently gained in popularity, is fundamentally correct. Nevertheless, the arguments in its favour have focused on either the conceptual similarities between the psalm and Ephesians ${ }^{10}$ or Paul's use of Psalm 68:18 in light of the end of the psalm. ${ }^{11}$

To be sure, there are conceptual similarities between Psalm 68 and Ephesians 4:8, and Paul most likely quoted Psalm 68:18 in light of the end of the psalm, the emphasis of which on divine strength coheres with Paul's theological interests in Ephesians. But more fundamentally,

Ephesians 4:8 in Light of the Ancient Versions', BSac 148 (1991): 319-36. Whereas the LXX exactly renders the Hebrew text, Paul's quote differs in four ways: (1) the use of

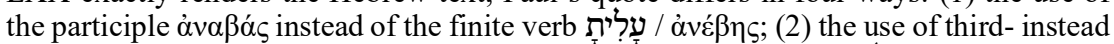
of second-person verb endings; (3) the use of है $\delta \omega \kappa \varepsilon v$ instead of

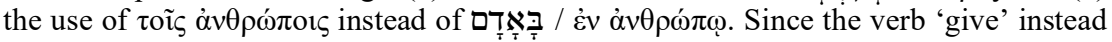
of 'receive' is attested in the Psalms Targum, the Syriac Peshitta, and some early church fathers, perhaps Paul used a different text-form from what is attested in the MT/LXX. Nevertheless, there are good reasons to question this view. The Psalms Targum postdates Ephesians as a written document, of whose prior oral tradition neither Paul nor the Ephesian recipients may have been aware. Further, the OT Peshitta may have been edited by Christians, rendering it difficult to rely on as an independent witness to a different text-form. This same point can be applied to the early church fathers as well, even when they quoted the OT to construct a Christian apologetic toward Judaism. Hence, though the question of the text-form is complex and uncertain, Frank Thielman's verdict seems judicious: 'the balance of the evidence favors the view that Paul himself changed the text of the psalm so that it conformed better to his concerns in 4:7-16.' Frank Thielman, Ephesians (BECNT; Grand Rapids: Baker Academic, 2010): 267.

9 E.g. Timothy G. Gombis, 'Cosmic Lordship and Divine Gift-Giving: Psalm 68 in Ephesians 4:8', NovT 47 (2005): 367-80; Jonathan M. Lunde and John Anthony Dunne, 'Paul's Creative and Contextual Use of Psalm 68 in Ephesians 4:8', WTJ 74 (2012): 99117; Grant R. Osborne, 'Hermeneutics and Paul: Psalm 68:18 in Ephesians 4:7-10 as a Test Case' in Studies in the Pauline Epistles: Essays in Honor of Douglas J. Moo, ed. Matthew S. Harmon and Jay E. Smith (Grand Rapids: Zondervan, 2014): 159-77; Todd A. Scacewater, The Divine Builder in Psalm 68: Jewish and Pauline Tradition (LNTS, 631; London: T\&T Clark, 2020); Frank S. Thielman, 'Ephesians' in Commentary on the New Testament Use of the Old Testament, ed. G. K. Beale and D. A. Carson (Grand Rapids: Baker Academic, 2007): 819-25; William N. Wilder, 'The Use (or Abuse) of Power in High Places: Gifts Given and Received in Isaiah, Psalm 68, and Ephesians 4:8', BBR 20.2 (2010): 185-200.

10 E.g. Gombis, 'Cosmic Lordship', rightly recognises the author 'is looking to the movement of the psalm as a whole' (373), is 'appropriating the narrative movement of the entire psalm' (375), and 'has in mind the full narrative movement of the entire psalm' (379). Yet how this is so is left unspecified beyond merely the general divine warfare and enthronement topos.

11 E.g. Osborne, 'Hermeneutics and Paul', 173; Wilder, 'The Use (or Abuse) of Power', 196-98. Richard James Lucas, Jr., 'Was Paul Prooftexting? Paul's Use of the Old Testament as Illustrated through Three Debated Texts' (Ph.D. dissertation, The Southern Baptist Theological Seminary, 2014): 142-43 contends that Eph. 4:8 quotes both Ps. $68: 18$ and $68: 35$. 
Paul's application of Psalm 68:18 to Christ owes to his recognition of the typological expectation within the psalm itself. That is, the psalm is both retrospective in that it tells Israel's past story and prospective in that it sets the stage for Israel's future story. The psalm uses earlier biblical texts that recount God's past saving acts (e.g. Exod. 15; Judg. 5) in order to establish an expectation of God's future saving acts. The psalm establishes the expectation that those future saving acts will correspond to, or be patterned after, the prior saving acts, yet they will also be greater in kind and extent. The psalm's retrospective and prospective orientation, which includes correspondence between God's saving acts and escalation throughout redemptive history, grounds the typological framework of the psalm and warrants Paul's application of the psalm to Christ, who eschatologically fulfils the psalm's typological expectation. ${ }^{12}$ Recognising the typological expectation of Psalm 68 both absolves Paul from the charge of hermeneutical insensitivity or 'prooftexting' and elucidates the foundational function of Psalm 68:18 in its Ephesianic context. ${ }^{13}$

12 The recent literature on biblical typology is immense. For an excellent discussion of what constitutes biblical typology, see Brent Evan Parker, 'The Israel-Christ-Church Typological Pattern: A Theological Critique of Covenant and Dispensational Theologies' (Ph.D. dissertation, The Southern Baptist Theological Seminary, 2017): 20-94. I understand biblical typology to include and require (1) correspondence between historical events, institutions, and persons, (2) escalation in the type-antitype relationship, and (3) a prospective orientation such that the type is intrinsically anticipatory, even if such appears only in embryonic form as it awaits further clarification and application through the progress of revelation. See also G. K. Beale, Handbook on the New Testament Use of the Old Testament: Exegesis and Interpretation (Grand Rapids: Baker Academic, 2012): 13-25; Aubrey Sequeira and Samuel C. Emadi, 'Biblical-Theological Exegesis and the Nature of Typology', Southern Baptist Journal of Theology 21.1 (2017): 11-34; Douglas J. Moo and Andrew David Naselli, 'The Problem of the New Testament's Use of the Old Testament' in The Enduring Authority of the Christian Scriptures, ed. D. A. Carson (Grand Rapids: Eerdmans, 2016): 725-37.

13 Rightly Allen P. Ross, A Commentary on the Psalms: Volume 2 (42-89) (Kregel Exegetical Library; Grand Rapids: Kregel Academic, 2013): 464. My thesis is supported by the independent analysis of Scacewater, Divine Builder in Psalm 68, who contends Ps. 68:19-35 is eschatological, that the eschatological interpretation of the psalm predated its Mosaic/Targumic interpretation, and that Paul applied the psalm typologically in Eph. 4:8. My analysis, while distinct in some of the exegetical minutiae, undergirds his argument by focusing more on the typological expectation of the psalm itself, particularly Ps. 68:19-35. 


\section{The Typological Expectation of Psalm 68}

In this section I will introduce Psalm 68 and analyse its typological indicators. Special attention will be given to the psalm's retrospective and prospective orientation, the probable allusions to Exodus 15 and Judges 5, and the typological expectation of Psalm 68:18.

\subsection{Introducing Psalm 68}

The theme of Psalm 68 is that God fights and wins his people's battles in order that he might dwell with his people as king. Divine victory for the purpose of divine presence is the focus of the psalm. ${ }^{14}$ Though some form critics doubt the literary integrity of the psalm, ${ }^{15}$ and despite uncertainty regarding the precise delimitation of the stanzas, ${ }^{16}$ the psalm divides into two sections (vv. 1-18 and 19-35), with verse 18 as the 'triumphant climax' of the first section. ${ }^{17}$ The first half recounts primarily God's past victories and the second primarily his future victories. In both halves,

14 Sometimes interpreters claim the psalm's dominant motif is either military victory (e.g. Osborne, 'Hermeneutics and Paul', 173 speaks of the 'centrality of military imagery') or divine presence (e.g. Gary V. Smith, 'Paul's Use of Psalm 68:18 in Ephesians 4:8', JETS 18.3 (1975): 185 claims it is the psalm's 'focal point'); Michael Gese, Das Vermächtnis des Apostels: die Rezeption der paulinischen Theologie im Epheserbrief (WUNT 2, 99; Tübingen: Mohr Siebeck, 1997): 185 claims 'Das thematische Zentrum dieses Psalms liegt in der Einwohnung Gottes auf dem Zion' ('the thematic centre of this psalm lies in the dwelling of God on Zion' (my translation)). But this is a false dichotomy, for both are necessary; the former inextricably leads to the latter. 15 E.g. Albright, 'Early Hebrew Lyric Poems', 1-39 suggested the psalm was a collection of independent poetic incipits or songs; cf. Hans Schmidt, Die Psalmen (HAT 1/15; Tübingen: Mohr Siebeck, 1934): 125-31. I concur with the analysis of John Philip Lepeau, 'Psalm 68: An Exegetical and Theological Study' (Ph.D. dissertation, University of Iowa, 1981): 234-73 that the division of the psalms in the MT is ancient and trustworthy, and that there are good arguments for the literary integrity of the psalm regardless of its use of prior materials and Sitz im Leben (cf. Sigmund Mowinckel, Der achtundsechzigste Psalm (Oslo: I kommisjon hos J. Dybwad, 1953): 9; Tate, Psalms 51100, 171-73).

16 Many commentators discern nine stanzas: vv. 1-3,4-6,7-10,11-14,15-18,19-23,2427,28-31,32-35, e.g. Sigmund Mowinckel, The Psalms in Israel's Worship, vol. 1 (Nashville: Abingdon, 1962; rev. and tr. from Norwegian, 1951): 172-74; Tate, Psalms 51-100, 185. Others discern twelve: vv. 1-3,4-6,7-10,11-14,15-16,17-18,19-20,2123,24-27,28-29,30-31,32-35, e.g. Kraus, Psalms 60-150, 48. Samuel Terrien, The Psalms: Strophic Structure and Theological Commentary (ECC; Grand Rapids: Eerdmans, 2003): 485-89 suggests the psalm contains eleven chiastic stanzas (with three vv. each), with vv. 16-18 as the 'core strophe'.

17 Thielman, 'Ephesians', 824; cf. Ross, Psalms, 466-67. Lucas, 'Was Paul Prooftexting?', 146 notes 'There is a progression that builds through the psalm, first to its climax in verse 18 and then even further leading up to the end.' 
divine victory is the sine qua non of, and prelude to, divine presence and recognition of divine kingship.

After an initial call to praise God for his ability to save his people and judge his enemies (Ps. 68:1-6), the psalmist recounts Israel's story at the time of the exodus (vv. 7-8), the conquest (vv. 9-10), and the judges (vv. 11-14). ${ }^{18}$ The narrative movement climaxes with YHWH's choice of Mount Zion to be his dwelling, where he is enthroned and recognised as Israel's king (vv. 15-18). The second half of the psalm (Ps. 68:19-35), which is a literary unit bound with a blessing formula (v. 19, 'Blessed is the Lord'; v. 35, 'Blessed is God'), continues the theme of divine victory and presence, but does so - note the numerous qal imperfect verbs - in anticipation of God's future acts of salvation. ${ }^{19}$ God is blessed because he is the God of our salvation (v. 19), delivering from death and the sea (vv. 20-23). He proceeds yet again into his sanctuary, sharing the victory with his people (vv. 24-27). The psalm concludes with a prayer that God would show his strength among the nations (vv. 28-31) as well as a final call for all peoples to sing and ascribe strength to God (vv. 32-35).

Throughout the psalm divine strength and kingship are on display. At the exodus God went out before his people, and like an army he marched through the desert (v. 7); the earth shook and the heavens rained at Sinai because of the greatness and might of God as king (cf. Exod. 19:16-19). That in verses 11-13 it is the women who are a great host, bearing good tidings of victory and dividing the spoil of war while the men lie down, indicates that Israel's mighty Warrior does not need the strength of men to win his battles. His names are Adonai (v. 11) and Shaddai (v. 14), and all he need do to win the victory is give his powerful word (v. 11). His ascension of Zion with captives in tow speaks to his total and complete subjugation of his enemies, and his reception of gifts from humanity indicates global recognition of his kingship and anticipates the building of the temple (v. 18). Thus the psalmist ascribes salvation to God as he anticipates future redemption (vv. 19-20), and the psalm's conclusion highlights divine strength and kingship (vv. 28-35).

The psalm as a whole thus brings together the themes of divine victory and divine presence. Psalm 68:18 is at the centre of the psalm both

\footnotetext{
18 Scacewater, Divine Builder in Psalm 68, 38-39 plausibly suggests that 68:4-6 begins the narrative proper by praising God for his deliverance of Israel at the time of the exodus. 19 See J. P. Fokkelman, 'The Structure of Psalm 68' in In Quest of the Past: Studies on Israelite Religion, Literature and Prophetism: Papers Read at the Joint British-Dutch Old Testament Conference, Held at Elspeet, 1988, ed. A. S. Van der Woude (OtSt 26; Leiden: Brill, 1990): 72-83.
} 
structurally and conceptually inasmuch as it collocates both themes through YHWH's ascension, captives, and gifts received. This introduction to the psalm sets the stage for an analysis of the psalm's typological framework, in view of its retrospective and prospective orientation and its probable allusions to Exodus 15 and Judges 5.

\subsection{The Retrospective and Prospective Orientation of Psalm 68}

The structure of Psalm 68 is both retrospective and prospective in orientation. It recounts Israel's past story and anticipates Israel's future story. This in itself is not a typological indicator, for typology is sustained by means of correspondence as well as escalation. In the case of Psalm 68 , however, the prospective is not unrelated to but is patterned after the retrospective. Generally, the pattern in both sections is victory $\rightarrow$ ascension $\rightarrow$ temple gifts. As seen in Table 1, divine victory precedes divine ascension and enthronement, which in turn precedes gifts of tribute and worship that build and maintain the temple. ${ }^{20}$

Table 1: The General Retrospective and Prospective Pattern of Psalm 68

\begin{tabular}{lll} 
Pattern & Retrospective (68:1-18) & Prospective (68:19-35) \\
\hline Victory & $68: 7-14$ & $68: 19-23$ \\
Ascension & $68: 15-18 \mathrm{a}$ & $68: 24-27$ \\
Temple Gifts $^{21}$ & $68: 18 \mathrm{~b}$ & $68: 28-31$
\end{tabular}

Undergirding this general pattern are verbal links in both sections. This verbal correspondence establishes the expectation that God's future acts will correspond to his past acts. As seen in Table 2, there is remarkable verbal correspondence between the retrospective and prospective sections of the psalm. ${ }^{22}$

20 This pattern is similar to that found in Scacewater, Divine Builder in Psalm 68, 5161, who shows the existence of a divine builder literary topos in the ancient Near East, whereby 'a god or a king defeats his enemies and then builds a temple for himself (the god) or for his god (the king)' (p. 60).

21 To be sure, the words for 'gifts' are not the same: מַתננוֹת (68:18) and (68:29). But they are both linked to the building and maintenance of the temple and are glad-hearted expressions of worship of the one true God as king.

22 The list of terms here is not exhaustive but tabulates only those terms deemed most relevant in order to establish a typological link between the psalm's two halves. 
Table 2: Retrospective and Prospective Verbal Correspondence in Psalm 68

\begin{tabular}{|c|c|c|}
\hline Verbal Links & $\begin{array}{l}\text { Retrospective } \\
(68: 1-18)\end{array}$ & $\begin{array}{l}\text { Prospective } \\
(68: 19-35)\end{array}$ \\
\hline 'Enemies' (אָיְבְים) & $68: 1$ & $68: 21,23$ \\
\hline ‘Sing' (שיר) & $68: 4$ & $68: 32$ \\
\hline 'Make melody' (זמר) & $68: 4$ & $68: 32$ \\
\hline 'Rider' (רֵֶב) & 68:4 (cf. רֶֶֶ, 68:17) & $68: 33$ \\
\hline ‘Sanctuary’ (קדֶׁש) & $68: 5,17$ & $\begin{array}{l}\text { 68:24, } 28: 35 \text { ) } \\
\text { (cf. }\end{array}$ \\
\hline 'Go/bring out' (תָוֹצָאת ' יצא) & $68: 6-7$ & 68:20 \\
\hline 'People' (עַ) & 68:7 & $68: 30,35$ \\
\hline 'Selah' (סֶלָה) & $68: 7$ & $68: 19,32$ \\
\hline 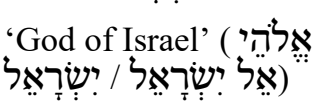 & $68: 8$ & $68: 35$ \\
\hline 'Lord' (אֶדנָנָי) & $68: 11,17$ & $68: 19,22,32$ \\
\hline 'Give' (נתן) & 68:11 (מתָתָנָה 68:18) & $68: 33-35$ \\
\hline 'Kings' (מְלְבִים) & $68: 12,14$ & $\begin{array}{l}\text { 68:29 מַמְלָכָה (cf. 68:32) } \\
\text { (cf) }\end{array}$ \\
\hline 'Bashan' (בָָָָּן) & $68: 15$ & $68: 22$ \\
\hline
\end{tabular}

This correspondence shows that the psalm's retrospective and prospective sections are closely related, for many of the same words are repeated. Both sections call for praise (vv. 4,32) and incorporate the musical term 'selah' when the story of redemption is about to be told (vv. 7,19). In both God is called 'Lord' and 'the God of Israel' (vv. 8,35). In both the name Bashan appears (vv. 15,22). In both, God appears as a 'rider' (vv. 4,33), and he 'goes out before' or 'brings back' (vv. 6-7,20) his 'people' (vv. 7,30,35), giving his powerful word (vv. 11,33-35). In both, his 'enemies' are defeated (vv. 1,21,23), 'kings' recognise his sovereignty (vv. 12,14,29), and he proceeds into his 'sanctuary' (vv. 17,24). The prospective section is thus patterned after the retrospective section; Israel's past story provides the blueprint for Israel's future story. $^{23}$

23 According to Scacewater, Divine Builder in Psalm 68, 102-17 early Judaism also interpreted the psalm along eschatological lines, as especially seen from the fragmentary 


\subsection{Allusions to Exodus 15 and Judges 5 in Psalm 68}

The typological expectation of the psalm is also seen in its allusions to Exodus 15 and Judges 5. As seen in Table 3, it resembles Exodus 15 in its language and theme. ${ }^{24}$

Table 3: Allusions to Exodus 15 in Psalm 68

\begin{tabular}{|c|c|c|}
\hline Term/Phrase & Exodus 15 & Psalm 68 \\
\hline 'Sing' (שיר) & $15: 1$ & $68: 4,32$ \\
\hline 'Melody' (זמרה / זמר) & $15: 2$ & $68: 4,32$ \\
\hline 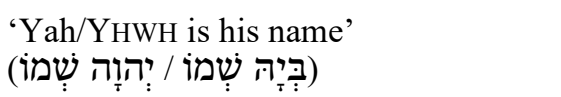 & $15: 2-3$ & $68: 4$ \\
\hline 'Strength' (ע) & $15: 2,13$ & $68: 28,33-35$ \\
\hline 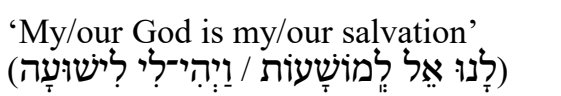 & $15: 2$ & $68: 19-20$ \\
\hline 'The sea' (יָם) and its 'depths' (מְצוֹלָה) & $15: 4-5$ & $68: 22$ \\
\hline ‘Sanctuary’ (מִקְדָּש / קָדֶש) & $15: 13,17$ & $68: 5,17,24,35$ \\
\hline 'Mountain' (הַ) & $15: 17$ & $68: 15-16$ \\
\hline
\end{tabular}

Both Exodus 15 and Psalm 68 are 'songs' of praise about God's kingship and salvation for his people. Both use a shortened form of the name YнwH: 'Yah' (Exod. 15:2; Ps. 68:4). Including Psalm 68:4, where appears the abbreviated name 'Yah', the phrase 'YHWH is his name' occurs five times in the Hebrew Bible, the first of which is in the Song of the Sea (Exod. 15:3; Jer. 33:2; Amos 5:8; 9:6). ${ }^{25}$ In Psalm 68, this same phrase occurs, albeit with YHWH's abbreviated name: 'Yah is his name'. Given the infrequency of the occurrences, its appearance in a victory song likely evokes Exodus 15. Further, both texts highlight God's 'strength', and both speak of God as having become 'our/my salvation'. In both, God destroys his enemy and saves his people from the 'sea', which is described as the 'depths' ${ }^{26}$ In both texts, God brings his people

pesher on Ps. 68 at Qumran (1Q16 = 1QpPs) as well as the grouping of Ps. 68 with Ps. 65-67 in the final form of the Hebrew Psalter.

24 For the exodus theme in the Psalter as a whole, see Allan M. Harman, 'The Exodus and the Sinai Covenant in the Book of Psalms', RTR 73.1 (2014): 3-27.

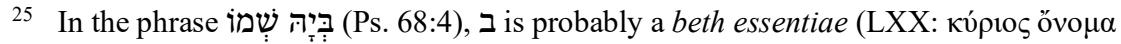

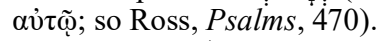

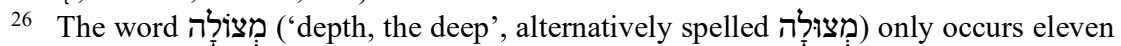
times in the MT: Exod. 15:5; Neh. 9:11; Job 41:23; Ps. 68:22; 69:2, 15; 88:6; 107:24; Jon. 2:4; Mic. 7:19; Zech. 10:11. 
to a mountain sanctuary where God will reign over them as king. Finally, both songs conclude with a celebration of God's kingship. The similarities between the two war songs suggest that Psalm 68 alludes to the language of Exodus 15 as it retold the story of the exodus and cast a vision for Israel's hope.

Psalm 68 also alludes to the Song of Deborah in Judges 5, as seen in Table $4 .{ }^{27}$

Table 4: Allusions to Judges 5 in Psalm 68

\begin{tabular}{|c|c|c|}
\hline Term/Phrase & Judges 5 & Psalm 68 \\
\hline 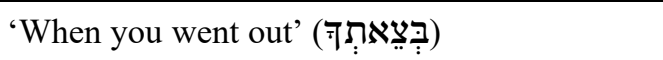 & $5: 4$ & $68: 7$ \\
\hline 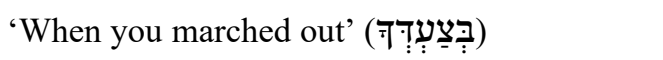 & $5: 4$ & $68: 7$ \\
\hline 'The earth trembled' (אֶרץ רָעָעָשָה) & $5: 4$ & $68: 8$ \\
\hline 'The heavens dropped' (שָמֵַים נָטְפוּ) & $5: 4$ & $68: 8$ \\
\hline 'The One of Sinai’ (זֶה סִינֶ) & $5: 5$ & $68: 8$ \\
\hline 'The God of Israel' (אֶלהַי יִשְָָׁרֵל) & $5: 5$ & $68: 8$ \\
\hline Benjamin, Zebulun, Naphtali & $5: 14,18$ & 68:27 \\
\hline Tribal 'princes' (שׁِר) & $5: 15$ & 68:27 \\
\hline 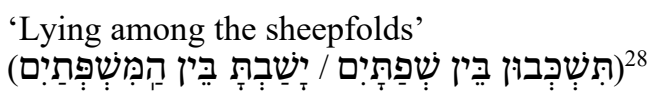 & $5: 16$ & $68: 13$ \\
\hline 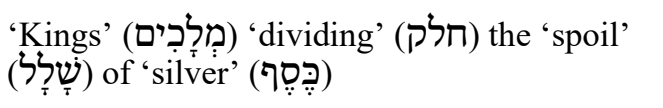 & $5: 19,30$ & $68: 12-13$ \\
\hline 'Strike' (מחץ) the 'head' (ראשץ) & $5: 26$ & 68:21 \\
\hline God's 'enemies' (איְיבים) will 'perish' (אבד) & $5: 31$ & $68: 1-2$ \\
\hline
\end{tabular}

27 For a discussion of some of these allusions, see Shoshana Sussman, 'Psalm 68: Echoes of the Song of Deborah', JBQ 40 (2012): 238-240; Lunde and Dunne, 'Paul's Creative and Contextual Use', 114 n. 63. For a similar figure produced independent of mine, see Scacewater, Divine Builder in Psalm 68, 85. In addition to these (but perhaps less likely) is that the 'bulls/steeds' (אַבְבירים) in Ps. 68:30 refers to the 'steeds' (אַבְבירים) of Sisera (Judg 5:22). Sussman, 'Psalm 68', 239 suggests that there are even 'similarities in cadence' between Ps. 68:15 and Judg. 5:21.

28 In Judg. 5:16 the term translated here as 'sheepfolds' is wheren in

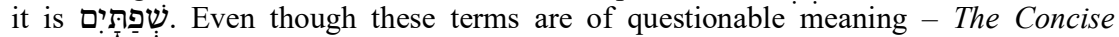
Dictionary of Classical Hebrew proffers for both the gloss 'fire-places' or 'ash-heaps' (from שפת , 'to set on fire'; The Concise Dictionary of Classical Hebrew (CDCH), ed. David J. A. Clines (Sheffield: Sheffield Phoenix Press, 2009): 252, 477) - it is enough to note that they likely derive from the same root. 
The clearest allusion to the Song of Deborah echoes Judges 5:4-5, which Psalm 68:7-8 quotes with minor variations (cf. Deut. 33:2). Both texts speak of God 'going out' and 'marching out', at which time 'the earth trembled' and 'the heavens dropped' rain before God. Both texts utilise the redundant phrase 'before YHWH/Elohim' at the same place, and both speak of God as 'the One of Sinai' - the only two instances of the phrase in the Hebrew Bible - and 'the God of Israel'. There are other allusions. Both texts name Benjamin, Zebulun, and Naphtali as well as tribal 'princes'. In Psalm 68:13, the parenthetical remark 'though you men lie among the sheepfolds' is almost a verbatim quote from Judges 5:16, where the tribe of Reuben, along with a few other tribes of Israel, is rebuked for failing to join the war effort against Sisera. The women in Psalm 68:11-13 who bear good tidings of victory and are depicted as dividing the spoil among themselves perhaps refer to Deborah and Jael, who bore good tidings of victory. Further, both texts speak of the Canaanite kings Israel defeated and the spoil of silver to be had through the war effort. Both describe how God crushes or 'strikes' the 'head' of his enemies. Finally, both include a prayer - at the end of the Song of Deborah and at the beginning of Psalm 68 - that God's 'enemies' will 'perish' and that the righteous will rejoice and be strong.

The tables above establish that Psalm 68 alludes to Exodus 15 and Judges 5, both in the retrospective and prospective sections of the psalm. That is to say, the psalm uses the language of Israel's prior war songs to tell Israel's past story as well as those same war songs to portray Israel's future story. To be sure, the use of prior tellings of a story in retelling that same story is hardly surprising. ${ }^{29}$ It is, rather, the use of prior tellings of a story in order to forecast a future story that is revealing and lays the groundwork for typology. For instance, when in Psalm 68:19-23 God is described as 'our salvation' who in the future will 'bring back from the depths of the sea' - evoking the language of the Song of the Sea - it creates the expectation that God's future deliverance of his people will be patterned after the deliverance by the sea. Again, when God's deliverance is followed in Psalm 68:24-27 by songs from women with tambourines - evoking the Song of Miriam after the deliverance at the sea (Exod. 15:20-21) - it creates the expectation that God's future saving

29 Indeed, Deborah crafted her song to fit the language and theme of the Song of the Sea; see Alan J. Hauser, 'Two Songs of Victory: A Comparison of Exodus 15 and Judges 5' in Directions in Biblical Hebrew Poetry, ed. Elaine R. Follis (JSOTSup 40; Sheffield: JSOT Press, 1987): 266-80. 
acts will issue in new songs of deliverance patterned after the Song of Miriam. ${ }^{30}$ When Psalm 68:21 speaks of God in the future 'striking the heads of his enemies' - evoking Deborah's description of Jael 'crushing the head and striking the temple' of Sisera (Judg. 5:26) - it establishes the expectation that God's future victory over his enemies will be patterned after his past victory over Jabin and Sisera. ${ }^{31}$ Finally, that in Psalm 68:27 the same tribes of Israel who joined Barak's war effort appear in a future triumphant procession with God establishes the hope of a future victory patterned after past victory. That the allusions to Exodus 15 and Judges 5 are not limited to merely the retrospective section but are included in the psalm's prospective section grounds the psalm's typological expectation wherein God's future saving acts would correspond to and exceed his past saving acts.

\subsection{The Typological Expectation of Psalm 68:18}

Since Paul quotes Psalm 68:18 in Ephesians 4:8, it will be helpful to develop briefly the typological expectation of Psalm 68:18 in particular. The three elements in the verse - ascension, captives, and gifts correspond to and are surpassed by similar elements in the prospective section of the psalm. ${ }^{32}$

\section{a. God's ascension}

God's ascension into his dwelling evinces correspondence and escalation. In the first half of the psalm, God's dwelling is with his people on earth. He rides through deserts (v. 4), ${ }^{33}$ marches through the wilderness (v. 7), and is associated with the mountains of Sinai and Zion

\footnotetext{
30 Scacewater, Divine Builder in Psalm 68, 88-89 notes that the Psalms Targum interpreted Ps. 68:24-27 in this way.

31 This point is undergirded by the likelihood that Judg. 5:26 and Ps. 68:21 also allude to Num. 24:17, which prophesies that a messianic figure would 'strike' (מחץ) the forehead of Moab (Scacewater, Divine Builder in Psalm 68, 117).

32 The threefold structure of v. 18 is supported by the metrical analysis of Kraus, Psalms $60-150,48$, in which v. 18 follows a $2+2+3$ meter. The significance of this, as seen in the analysis below, is that the subjugated captives are not coextensive with the gift-givers from humanity.

33 The term עִ עָרבָּוֹ (v. 4) is rightly translated 'deserts' and refers to an arid region (BDB

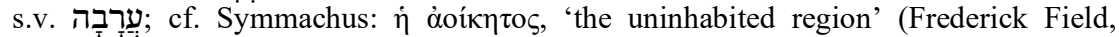
Origenis Hexaplorum Quae Supersunt, Sive Veterum Interpretum Graecorum in Totum Vetus Testamentum Fragmenta, vol. 2 (Oxford: OUP, 1875: 199)). Some interpreters emend the text to עִ עִרפוֹת on the basis of Ugaritic rkb 'rpt as an attribute of Baal the 'Cloud

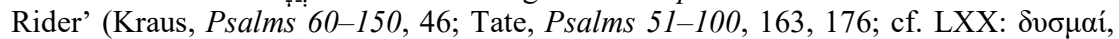
'settings'). But such lacks Hebrew manuscript evidence, and it is needless due to the exodus motif in the psalm (so Ross, Psalms, 469).
} 
(vv. 15-18). God 'goes out' (v. 7) before his people in order to redeem them, and then climactically ascends to dwell with them in his 'sanctuary' (v. 17). Correspondingly, in the prospective section YHWH once again 'goes out' (v. 20) before his people in order to redeem them (vv. 19-23), and then proceeds once more into his 'sanctuary' (v. 24). God's procession in the midst of his people evokes the ark of the covenant's entrance into Jerusalem, accompanied by singers and dancers (vv. 24-27; cf. 2 Sam. 6). That it is cast as a future procession indicates a future ascension into a future dwelling. Although Sigmund Mowinckel's thesis that the psalm's Sitz im Leben was linked with an autumnal YHWH festival is questionable, he rightly noted that the enthronement psalms, among which Psalm 68 belonged, had both a retrospective and prospective character; they looked back with thankfulness for YHWH's past and present reign as well as anticipated YHWH's future reign. ${ }^{34}$ The psalm's typological outlook established Israel's hope that YHWH's eschatological redemption would prelude his eschatological enthronement wherein the nations would recognise him as king and he would dwell among his people in an eschatological temple (cf. Ezek. 40-48; Zech. 14:9).

Supporting this ascension typology is the psalm's spatial escalation from earth to heaven. While in the first half God is 'the rider in the deserts' (v. 4), in the second he is 'the rider in the heavens of the ancient

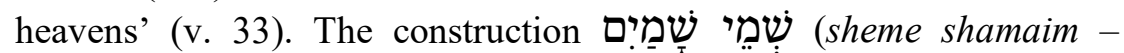
'heavens of heavens') probably is a periphrasis for the superlative, ${ }^{35}$ indicating YHWH rides in the highest heaven, which depicts his exalted status and universal sovereignty. The spatial imagery continues in verse 34 where his presence is said to be 'over Israel' and 'in the clouds' ${ }^{36}$ The spatial shift from earth to heaven shows that God has not only an earthly dwelling but also, in a more fundamental and greater way, a heavenly dwelling (cf. Isa. 66:1-2; Acts 7:48-50). It has been his dwelling 'from

\footnotetext{
34 Mowinckel, Psalms in Israel's Worship, 186-92.

35 See GKC §133i; Ross, Psalms, 480; Tate, Psalms 51-100, 170.

36 Some interpreters suggest the psalm alludes to Canaanite mythology's depiction of Baal as a 'Cloud Rider' for polemic purposes, e.g. Michael S. Heiser, The Unseen Realm: Recovering the Supernatural Worldview of the Bible (Bellingham, Washington: Lexham, 2015): 181; Robert D. Miller, 'The Gentiles in the Zion Hymns: Canaanite Myth and Christian Mission', Transformation 26.4 (2009): 232-46, esp. 235; W. Hermann, 'Rider upon the Clouds' in Dictionary of Deities and Demons in the Bible (DDD), ed. Karel van der Toorn et al. ( $2^{\text {nd }}$ edn; Grand Rapids: Eerdmans, 1999): 703-705. On the contrary, the background for Ps. 68:33-35 may derive from Deut. 33:26 (Scacewater, Divine Builder in Psalm 68, 64-65). In any case, YHwH's exalted status is clear.
} 
of old' (v. 33, קֶ?ִ - qedem) and will be consummately his dwelling forever. The 'sanctuary' of the earthly Zion (v. 17) thus corresponds to the eschatological 'sanctuary' in the heavenly Zion (v. 35). If this is correct, then the references to the 'sanctuary' into which YHWH proceeds (v. 24) and the temple 'over Jerusalem' (v. 29) to which kings bring their gifts correspond to the eschatological heavenly temple (cf. Heb. 12:22) ${ }^{37}$ The spatial escalation from YHWH's ascension and dwelling on earth to his greater ascension and dwelling in heaven means that YHWH's ascension in Psalm 68:18 typified a greater, eschatological ascension into a heavenly temple.

\section{b. God's captives}

Similarly, YHWH's captives in Psalm 68:18 correspond to and typify eschatological captives. In the psalm's first half, God's enemies are depicted as human beings, probably kings of the nations surrounding Israel. They are the 'rebellious' (v. 6) and 'the kings of the armies' (v. 12; cf. v. 14). The reference to Bashan in verse 15 evokes the defeat of Og before Israel entered Canaan (Num. 21:31-35; Deut. 3:1-11). Probably the captives in verse 18 are also God's enemies, perhaps referring to all the enemies vanquished during the time of the conquest (cf. Judg. 5:12). שבי (shvh) with its cognate accusative (shvy) - 'to take captive captives' - appears in six other instances in the Hebrew Bible (Num. 21:1; Deut. 21:10; Judg. 5:12; 2 Chr. 28:5,11,17), each time referring to capturing one's enemy. ${ }^{39}$ In the second half of the psalm, God's enemies are described in similar terms. Once again God's

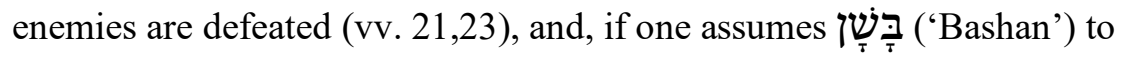
be a place name (although see below), Bashan is once again the place from which God will deliver his people (v. 22) ${ }^{40}$ God's deliverance from the 'depths of the sea' (v. 22) evokes the language of the exodus,

\footnotetext{
37 Tate, Psalms 51-100, 168 suggests the temple's being 'over Jerusalem' may have a double meaning, referring both to the historical temple in Jerusalem and the heavenly temple.

38 Ross, Psalms, 475; Terrien, Psalms, 494.

39 Contra Gary Smith, 'Paul's Use of Psalm 68:18', 181-89, who proposes that the captives are Levites whom God set aside to minister among his people. The problem is that the Levites were not God's enemies, nor were they ever identified as God's captives (rightly Harold W. Hoehner, Ephesians: An Exegetical Commentary (Grand Rapids: Baker Academic, 2002): 528).

40 This identification of Bashan as bound up with God's enemies is found elsewhere in the OT (cf. Ps. 22:12; Isa. 2:13; Ezek. 39:18).
} 
suggesting that the enemies God will deliver his people from correspond to their past enemies.

But God's future captives not only correspond to the past captives; they also surpass them. Death and the sea (vv. 20,22), in addition to recalling the exodus, may refer to the Canaanite gods Mot and Yam. ${ }^{41}$ According to Canaanite mythology, Baal was the archenemy of Mot, the god of death, but the point in verse 20 'is that YHWH, not Baal, can deal with Mot'. ${ }^{42}$ Similarly, Baal is said to have fought and defeated Yam, the god of the sea, as a prelude to his enthronement and the building of his temple. ${ }^{43}$ But again, in verse 22 it is YHWH, not Baal, who delivers his people from the sea as a prelude to his enthronement as king and the building of the temple. To press the argument further, if in verse $22 \mathrm{~b}$ we have a reference to YHWH's defeat of Yam, then in the corresponding colon in verse 22a it is likely that בָָָּ ('Bashan') refers to the serpent of the sea. On the strength of evidence from the cognate languages of Ugaritic, Akkadian, and Arabic, HALOT and $C D C H$ list two separate entries for בששן, with the second having the meaning of 'serpent' or 'snake' (cf. Deut. 33:22). ${ }^{44}$ While the appearance of בשטן in verse 15 as a place name may suggest the same referent in verse 22,45 it is more likely that the psalmist used a homographic wordplay to advance the typological expectation of the psalm. If this is the case, then the escalation between God's past and future victories is clear, for God's defeat of $\mathrm{Og}$ and his kingdom prefigures and anticipates his greater defeat of the 'serpent', whose domain is the sea (see Job 41:1-34; Ps. 74:13-14; Isa. 27:1) and who has power over death (Heb. 2:14-15; cf.

41 For the link between the sea and chaos, see Othmar Keel, The Symbolism of the Biblical World: Ancient Near Eastern Iconography and the Book of Psalms (New York: Seabury, 1978; tr. from German, 1972; repr., Winona Lake, Indiana: Eisenbrauns, 1997): 74-75.

42 Tate, Psalms 51-100, 181.

43 Jakob H. Grønbæk, 'Baal's Battle with Yam: A Canaanite Creation Fight', JSOT 33 (1985): 27-44, esp. 33-34. For the text of the Canaanite myths, see Die keilalphabetischen Texte aus Ugarit, Ras Ibn Hani und anderen Orten, ed. Manfried Dietrich et al. ( $3^{\text {rd }}$ edn; AOAT 360/1; Münster: Ugarit-Verlag, 2013): 1.2 iii.

44 HALOT (1:165): 'serpent'; CDCH (57): 'snake'. See James H. Charlesworth, 'Bashan, Symbology, Haplography, and Theology in Psalm 68' in David and Zion: Biblical Studies in Honor of J. J. M. Roberts, ed. Bernard F. Batto and Kathryn L. Roberts (Winona Lake: Eisenbrauns, 2004): 352-54; F. Charles Fensham, 'Psalm 68:23 in the Light of the Recently Discovered Ugaritic Tablets', JNES 19 (1960): 292-93; G. del Olmo Lete, 'Bashan' in $D D D, 161-63$.

If בשנ Is a place name, then as a mountainous region it is to be set in contrast with the sea, indicating God's ability to bring back from the heights and depths (Amos 9:2-4; so Kraus, Psalms 60-150, 50). 
Rev. 12:7-13:1). ${ }^{46}$ More evidence for escalation in the psalm is that the beasts in the reeds and the herd of bulls probably refer to the gods of Egypt or the evil powers of chaos (v. 30; cf. Job 40:21; Ezek. 29:3-4) ${ }^{47}$ Of the figure of a bull in particular, Othmar Keel has noted that since bulls depict great power, in the ancient Near East they can 'illustrate the mighty powers attributed to a number of evil demons'. ${ }^{48}$ The use of animal imagery in the second half of the psalm adds a new element and suggests that the vanquished enemy is not merely human but also demonic; God's defeat of the nations in the first half of the psalm anticipates his defeat of the nations' gods in the second. ${ }^{49}$ The intrapsalmic shift from human to suprahuman captives indicates that YHWH's human captives in Psalm 68:18 typify eschatological captives subjugated by his eschatological victory.

\section{c. God's gifts}

The gifts YHWH receives in Psalm 68:18 correspond to and typify eschatological gifts. The gifts in verse 18 are likely gifts for the construction and maintenance of the temple, since the purpose of the gifts - note the telic infinitive construct ?ִשְׁכּן (lishkon) - is "so that Yah Elohim may dwell there'. ${ }^{50}$ The gifts are 'from humanity', which probably depicts how the nations joined Israel in contributing to the temple's construction (cf. $1 \mathrm{Kgs} 7: 13 ; 10: 10-12) .{ }^{51}$ While the reference

46 Similarly, Heiser, The Unseen Realm, 145, 207-209 suggests Bashan is associated with the place of demons, death, and the serpent.

47 Kraus, Psalms 60-150, 55; Mowinckel, Psalms in Israel's Worship, 173-74; Terrien, Psalms, 496; cf. Clinton E. Arnold, Ephesians (ZECNT; Grand Rapids: Zondervan, 2010): 247. Tate, Psalms 51-100, 183-84 thinks the psalm uses the language of Egypt and the forces of chaos to refer to kings and armies who set themselves up against God. Scacewater, Divine Builder in Psalm 68, 105-106 notes that 1Q16 (1QpPs), though fragmentary, probably links the beast of the reeds with the Kittim, the end-time enemy of God.

48 Keel, Symbolism of the Biblical World, 86.

49 Yet another indication of the type of enemies envisioned is that ('hair', v. 21) may be a wordplay on שָׁעִ (he-goat's form as a demon). See Mowinckel, Psalms in Israel's Worship, 173-74; cf. Arnold, Ephesians, 247.

50 Rightly Scacewater, Divine Builder in Psalm 68, 46-49; Martin Foord, 'Taking with One Hand, and Giving with the Other? The Use of Psalm 68:18 in Ephesians 4:8' in All That the Prophets Have Declared, ed. Matthew R. Malcolm (Croydon: Paternoster, 2015): 127-38.

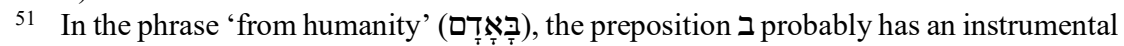
sense and is not a beth essentiae (rightly Tate, Psalms 51-100, 166). While Scacewater, Divine Builder in Psalm 68, 46-49 convincingly shows the gifts were for the temple, his limiting the gifts to voluntary contributions by Israelites overlooks that the gifts came 'from humanity'. 
to the 'rebellious' in verse 18 may indicate that the gifts include war spoils from the subjugated, more likely they include glad-hearted gifts of מַת מָנוֹת (mattanot - 'gifts') typically connotes gifts of devotees to a deity. ${ }^{52}$ Similarly, in verse 29 future kings would come bearing gifts of tribute in glad-hearted recognition of God as king. These too would be 'on account of' God's temple, ${ }^{53}$ for their recognition of God as king necessitates tangible gifts of adoration for use in the temple. Since the psalm concludes with a call for global recognition of God as king (v. 32), the implication is that the kind and extent of eschatological temple gifts would exceed even that which was obtained for Solomon's temple. YHWH's reception of gifts in Psalm 68:18 thus corresponds to and typifies his reception of gifts from the nations for the construction of the eschatological temple.

Since in Ephesians 4:8 Paul's quote differs from Psalm 68:18 such that Christ gave gifts instead of received them, it will be helpful to note briefly the relationship between YHWH's reception of gifts in verse 18 and his role as Giver in the rest of the psalm. In Psalm 68 God is the preeminent Giver of redemption: he is a father to the fatherless, protects widows, settles the solitary in a home, leads prisoners into prosperity, marches before his people, sheds abroad rain, restores his inheritance, provides for the needy, bears up his people, delivers from death, brings back from Bashan, and commands strength for his people. The proliferation of gift language in verses 33-35 highlights and brings to a climax the divine gift character of the entire psalm.

Further, the gift of redemption comes through his powerful word; it is

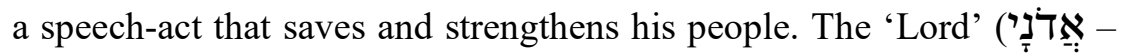
'adonay) gives a word of salvation twice in the psalm (vv. 11,22), and not surprisingly, the first word-gift typifies the second. In the time of the judges, God declared victory over Jabin and Sisera, and this declaration בשר : enabled God's people to 'spread the good tidings' (vv. 11-12; MT

52 Including Ps. 68:18, מַתָנוֹת is used eighteen times in the Hebrew Bible. The term can refer to human-to-human gifts (Gen. 25:6; 2 Chr. 21:3; Esth. 9:22; Ezek. 46:16-17), bribe gifts (Prov. 15:27; Eccl. 7:7), the Levites or the priesthood as gifts (Num. 18:6-7), and, as here, offerings to a deity (to YHwh, Exod. 28:38; Lev. 23:38; Num. 18:11,29; Deut. 16:17 or idols, Ezek. 20:26,31,39). Israel would offer gifts of worship and devotion to YHWH at their feasts (Deut. 16:17) as a part of their regular offerings (Lev. 23:38; Num. 18:11,29).

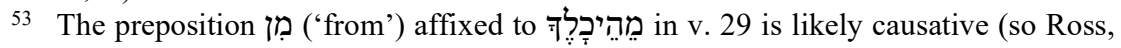
Psalms, 479). 


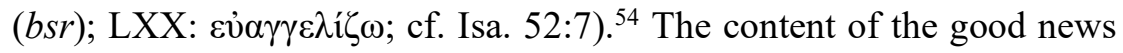
appears as a verb repeated for emphasis: 'they flee, they flee!' (v. 12, ידידוּן יידידוּן - yiddodhun yiddodhun). Later in the psalm, God again declares victory, and yet again the verb is repeated for emphasis: 'I will bring back, I will bring back' (v. 22, אָָָׁיב אִָׁיב - 'ashiv 'ashiv). The two word-gifts thus correspond, the primary difference being the promissory and escalated nature of the second (vv. 19-23). God's earlier salvific speech-act established Israel's hope for a greater salvific speechact. Accordingly, the psalm concludes with a call for the nations to put their hope in God's 'voice of strength' (v. 33). ${ }^{55}$ In light of the psalm's emphasis on God as the pre-eminent Giver, we can conclude that the basis for YHWH's reception of temple gifts in verse 18 is his prior gift of redemption; he gives in order to receive. He redeems through his powerful word and is enthroned as king with the subjugated in tow. This act of victory and ascension elicits from his people a message of glad tidings and contributions for the building and maintenance of the temple.

\section{The Application of Psalm 68:18 in Ephesians 4:8}

Thus far I have established the typological expectation of Psalm 68 in view of its retrospective and prospective orientation and its allusions to Exodus 15 and Judges 5. In light of this I analysed the typological expectation of the three elements in Psalm 68:18: ascension, captives, and gifts. This analysis sets the stage for discerning Paul's application of Psalm 68:18 to Christ's ascension, taking captives, and giving gifts in Ephesians 4:8. Discerning the typological expectation of Psalm 68 aptly illustrates Paul's hermeneutical approach and elucidates the function of Psalm 68:18 in its Ephesianic context.

\subsection{Introducing Ephesians 4:8}

Ephesians 4-6 outlines the necessity and nature of walking worthy of the call to which Christians have been called (4:1). ${ }^{56}$ The initial section (vv. 1-16) emphasises both unity in Christ through the Spirit because of the gospel (vv. 1-6) and the diversity the church experiences due to Christ's

54 So Tate, Psalms 51-100, 178.

55 The preposition $ב$ in v. 33 is instrumental ('by means of'). The double occurrence of קו ('voice') in v. 33 highlights the power of God's word.

56 The verb $\pi \varepsilon \rho ı \pi \alpha \tau \dot{\varepsilon} \omega$ ('to walk') is a keyword occurring regularly and at crucial junctures in this section $(4: 1,17 ; 5: 2,8,15 ; \mathrm{cf} .2: 2,10)$. 
variegated gifts to the church (vv. 7-16). The latter section focuses on the individual Christian - it begins with the individualising 'each one' (v. 7) and ends with a reference to 'each part' of the body working to build up the body (v. 16). As seen in Figure 1, verses 7-10 establish Christ as the church's ascended and victorious Giver, and verses 11-16 depict the application of his gifts to the upbuilding of the church.

\begin{tabular}{|c|c|c|}
\hline Main point & 7 & To each one Christ gave grace \\
\hline \multirow{3}{*}{ Psalm 68:18 cited } & $8 \mathrm{a}$ & He ascended on high \\
\hline & $8 b$ & He captured captives \\
\hline & $8 \mathrm{c}$ & He gave gifts to people \\
\hline \multirow{5}{*}{$\begin{array}{l}\text { Commentary on v. 8ab: } \\
\text { Christ as ascended and } \\
\text { victorious }\end{array}$} & $9 a$ & He ascended \\
\hline & $9 b$ & $\begin{array}{l}\text { He descended into the lower } \\
\text { regions }\end{array}$ \\
\hline & $10 \mathrm{a}$ & The one who descended \\
\hline & $10 \mathrm{~b}$ & The one who ascended \\
\hline & & In order to fill all things \\
\hline $\begin{array}{l}\text { Commentary on v. 8c: } \\
\text { Christ as gift-giver }\end{array}$ & $11-16$ & $\begin{array}{l}\text { He gave ministers of the word to build } \\
\text { up the body }\end{array}$ \\
\hline
\end{tabular}

Figure 1: The Structure of Ephesians 4:7-16

The structure shows that verse 7 is the main point: Christ is the Giver of gifts to his church. ${ }^{57}$ The reality of Christ as Giver leads Paul to conclude - verse 8 begins with the inferential conjunction $\delta$ ó ('therefore') - that Psalm 68:18 is fulfilled in Christ. The quote has three elements: ascension, ${ }^{58}$ captives, and gifts. These three components are then commented on in turn in the following verses. ${ }^{59}$ Christ's ascension in

57 This point is made by many commentators, e.g. Hoehner, Ephesians, 521; Andrew T. Lincoln, Ephesians (WBC 42; Grand Rapids: Zondervan, 1990): 241.

58 The participle $\dot{\alpha} v \alpha \beta \alpha$ ś ('ascending') functions as an attendant circumstantial participle, aligning with four of the five features of such (Daniel B. Wallace, Greek Grammar Beyond the Basics: An Exegetical Syntax of the New Testament (Grand Rapids: Zondervan, 1996): 642). This suggests it is contemporaneous with the action of the main

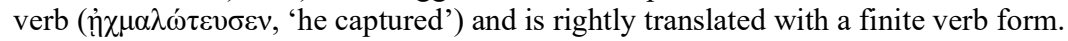

59 As a marker of development, $\delta \varepsilon$ ('now') in v. 9 begins a new step in Paul's argument as he begins to comment on the three elements in v. 8 . This is likely why v. 11 begins with $\kappa \alpha$ í ('and'), for it continues Paul's commentary on the psalm that he began in v. 9. See Steven E. Runge, Discourse Grammar of the Greek New Testament: A Practical Introduction for Teaching and Exegesis (Lexham Bible Reference Series; Peabody: Hendrickson, 2010): 23-27, 31-36. 
verse $8 \mathrm{a}$ is commented on chiastically in verses $9 \mathrm{a}-10 \mathrm{~b}$, and Christ's capture of captives in verse $8 \mathrm{~b}$ corresponds to Christ's descent in verses 9b-10a. ${ }^{60}$ Finally, Christ's giving of gifts in verse $8 \mathrm{c}$ corresponds to his giving the ministers of the word for the upbuilding of the church in verses 11-16. That Psalm 68:18 provides the structure for the entire subsection demonstrates its central significance for Paul. That the citation is inferred - again, note $\delta$ ió ('therefore') in verse 8 - suggests that the psalm's raison d'être was to typify Christ. ${ }^{61}$ Christ was the Giver of grace to his people (v. 7), and 'therefore' Psalm 68:18 was written. Given his Christology and grasp of redemptive history, Paul's awareness of the typological expectation of the psalm required him to apply it to Christ. Thus, Paul did not import an interpretation alien to the psalm; rather, Richard Lucas says it well: 'Paul reads this psalm christologically, but the psalm gave implicit permission to do so, and in light of Paul's place in redemptive history, there was no other way to understand this psalm for Paul. ${ }^{62}$ Paul's recognition of the psalm's typological expectation inextricably bound him to apply the ascension, captives, and gifts to Christ's victory over his enemies and the construction of the eschatological temple.

\subsection{Christ's Ascension}

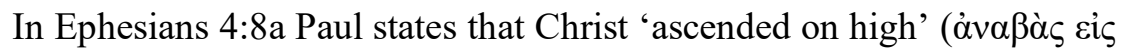

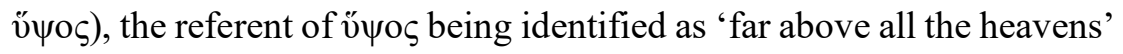
(v. 10b). Elsewhere in Ephesians Christ's dwelling is 'in the heavenly places' $(1: 3,20 ; 2: 6)$ and, with respect to the principalities and powers, he is exalted to the Father's right hand 'far above' them (1:20-21). Even

60 W. Hall Harris. The Descent of Christ: Ephesians 4:7-11 and Traditional Hebrew Imagery (Biblical Studies Library; Grand Rapids: Baker, 1996): 180 views all of vv. 711 as a chiasm, in which Christ's giving gifts to people in v. 8 corresponds to Christ's descended status in v. 10a. But his outline curiously has no place for Christ's leading a host of captives, which seems to fit more closely with the language of Christ's descent to the 'lower regions'. The chiastic structure of vv. 9-10 allows for various interpretations regarding the descent of Christ, which is beyond the scope of the analysis here.

61 So Charles Hodge, Commentary on the Epistle to the Ephesians (New York: Robert Carter, 1860; repr., Old Tappan, New Jersey: Fleming H. Revell, 1979): 213: 'This great truth is foreshadowed and foretold in the Old Testament Scriptures.' Similarly, S. M. Baugh, Ephesians (Evangelical Exegetical Commentary; Bellingham, Washington: Lexham, 2016): 321-22; Scacewater, Divine Builder in Psalm 68, 132-33. For $\delta$ iò $\lambda \varepsilon ́ \gamma \varepsilon 1$, see Eph. 5:14; Heb. 3:7; 10:5; Jas 4:6; Philo, Alleg. Interp. 3.172, 180. Occasionally interpreters will invert the argument of vv. 7-8; e.g. Hoehner, Ephesians, 523: 'Paul had just made a statement about the giving of gifts to each believer and this can be inferred from the OT passage of Scripture which he quotes' (my emphasis).

62 Lucas, 'Was Paul Prooftexting?', 147. 
though Psalm 68:18 refers to YHWH's ascent of the earthly Mount Zion, we saw that it anticipated a greater ascension into a greater heavenly dwelling. This typological expectation Paul applied to Christ's ascension, and the psalm's escalating spatial imagery matches Paul's language almost precisely. Christ did not ascend the earthly Mount Zion, but he ascended 'far above all the heavens', which corresponds to the

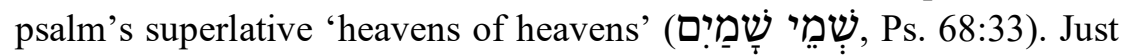
as the psalm claimed God to be 'the rider in the heavens of the ancient heavens' and have his glory 'in the clouds' (Ps. 68:33-34), so Paul applied that eschatological expectation to Christ's ascension into 'the heavenly places' (cf. Eph. 1:20; 2:6).

Similarly, just as the purpose of YHWH's ascension in Psalm 68:18 was a prelude to the temple's construction, so Christ's ascension in Ephesians 4:8 was a prelude to the eschatological temple. In Psalm 68:17-18, YHWH ascended in order to dwell in his earthly sanctuary with his people, anticipating another ascension into a greater, heavenly sanctuary (Ps. 68:24,29,35). This greater ascension and temple dwelling Paul applied to Christ, for the goal of Christ's ascension was 'in order to (iv $\alpha$ ) fill all things' (Eph. 4:10b). While Christ's 'filling all things' indicates his universal sovereignty - this coheres with YHWH's universal sovereignty in Psalm $68^{63}$ - it also is rooted in the Old Testament's descriptions of the glory of God filling the temple (cf. Exod. 40:34; 1 Kgs 8:11; Ezek. 43:5). If so, the temple that Christ fills is the new heaven and new earth ('all things'). This interpretation fits with the temple elsewhere in Ephesians, in which Christ is a temple builder (Eph. 2:1418 ) and those in Christ are built into a holy, eschatological temple (2:2022) ${ }^{64}$ Christ's victory, powerfully attested in his descent and subsequent ascension, inaugurated the eschatological temple, which continues to expand as Christ builds up his temple by means of his powerful word $(4: 11-16){ }^{65}$

63 So Arnold, Ephesians, 255; Hodge, Ephesians, 221; cf. Jeremiah 23:24.

64 Rightly Baugh, Ephesians, 328. See Larry J. Kreitzer, 'The Messianic Man of Peace as Temple Builder: Solomonic Imagery in Ephesians 2:13-22' in Temple and Worship in Biblical Israel, ed. John Day (London: T\&T Clark, 2005): 484-507; Andrew Mark Stirling, 'Transformation and Growth: The Davidic Temple Builder in Ephesians' (Ph.D. dissertation, University of St Andrews, 2012); Scacewater, The Divine Builder in Psalm $68,149-50$.

65 For the temple's construction as ongoing in Ephesians, see G. K. Beale, The Temple and the Church's Mission: A Biblical Theology of the Dwelling Place of God (NSBT 15; Downers Grove: IVP, 2004): 263. 


\subsection{Christ's Captives}

In Ephesians 4:8b Christ 'captured captives' (ท่ $\chi \mu \alpha \lambda \omega ́ \tau \varepsilon v \sigma \varepsilon v$ $\alpha i \chi \mu \alpha \lambda \omega \sigma i \alpha v)$, which closely corresponds to the Septuagint. ${ }^{66}$ While the noun $\alpha i \chi \mu \alpha \lambda \omega \sigma i$ í often refers to a 'state of captivity', it can also refer more concretely to 'a captured military force'. ${ }^{67}$ In Ephesians, the 'captured force' is likely the evil powers, who are identified as supernatural, powerful, malevolent beings. In Psalm 68:18, the verb שבה (shvh - 'to capture') with its cognate accusative consistently refers to capturing or subjugating one's enemy. Moreover, the $\alpha i \chi \mu \alpha \lambda \omega \sigma i \alpha$ ('captivity') word group in the New Testament always refers to capturing one's enemies. ${ }^{68}$ Also, the parallel text in Colossians 2:15 similarly speaks of God triumphing over 'the rulers and authorities', terms reminiscent of the evil powers and principalities in Ephesians. Finally, in Ephesians the enemies of God are the evil powers. In Ephesians 1:21 Jesus's ascended status is said to be 'far above all rule and authority and power and dominion', terms that likely include what 6:12 calls 'the cosmic powers over this present darkness, the spiritual forces of evil in the heavenly places' (cf. 3:10). These supernatural evil beings include the devil himself, who in 2:2 is called the 'prince of the power of the air, the spirit who is now at work in the sons of disobedience', and who in 6:16 is called the 'evil one' with 'flaming darts' (cf. 4:27). Paul even clarifies that these beings are ones Christians fight against, not flesh and blood (6:12). ${ }^{69}$ Thus, through his victorious life, death, resurrection, and ascension, Christ subjugated demonic beings. ${ }^{70}$ This interpretation of the powers as demonic beings fits with what we know regarding the pervasive influence of Hellenistic magic practices in and around

66 With the MT, LXX-Ps. 67:19 (Eng. 68:18) reads the second-person singular $\grave{n} \chi \mu \alpha \lambda \omega ́ \tau \varepsilon v \sigma \alpha \varsigma$.

${ }_{67}$ BDAG s.v. $\alpha i \chi \mu \alpha \lambda \omega \sigma i \alpha$; cf. LSJ (s.v. $\left.\alpha i \chi \mu \alpha \lambda \omega \sigma i \alpha\right)$ : 'body of captives'.

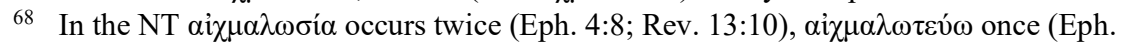
4:8), $\alpha i \chi \mu \alpha \lambda \omega \tau i \zeta \zeta \omega$ four times (Luke 21:24; Rom. 7:23; 2 Cor. 10:5; 2 Tim. 3:6), and

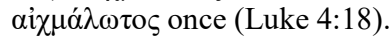

${ }^{69}$ For a more detailed analysis of the identity of the evil powers in Ephesians, see Joshua M. Greever, 'The Armor of God, the Gospel of Christ, and Standing Firm against the "Powers" (Ephesians 6:10-20)', Journal of Biblical and Theological Studies 5.1 (2020): 72-89, esp. 79-82.

70 So Hoehner, Ephesians, 529-30. Some think the captives are Christ's people that he sends out as gifts, e.g. Richard Dormandy, 'The Ascended Christ and His Gifts', ExpTim 109 (1998): 206-207. Muddiman, Ephesians, 191-92 considers the captives to be both the evil powers and God's people, but this is unlikely, for (1) the captives in Ps. 68:18 are God's enemies, not his people, and (2) in the quote God's people correspond to the gifts, not the captives. 
Ephesus, which included worship of the supreme goddess Artemis and the attempt to manipulate various spiritual powers for one's benefit (cf. Acts 19$){ }^{71}$

Therefore, the demonic forces Christ captured in Ephesians correspond to the nations' gods alluded to in Psalm 68: Death/Mot, the $\mathrm{Sea} / \mathrm{Yam}, \mathrm{Bashan} / \mathrm{Serpent}$, the beasts in the reeds, and the herd of bulls. Even though Paul does not utilise the same verbiage as the psalm to depict these evil powers, their referent appears to be the same. ${ }^{72}$ Paul identified the psalm's 'captives' as demons because he recognised that within the psalm itself God's past victories over his enemies provided the pattern for an eschatological victory in which God would defeat all of his enemies completely and utterly, whether those enemies be human, demonic, or the ancient serpent himself.

\subsection{Christ's Gifts}

In Ephesians 4:8c Christ gives gifts to his people. Christ's gift-giving is the main point of 4:7-16, as shown by the extended commentary on $4: 8 \mathrm{c}$ in verses 11-16. But precisely at this point is the text's crux interpretum, for Psalm 68:18 says YHWH received gifts from people, whereas Paul says Christ gave gifts to people. Assuming the stability of Paul's textform, what is the rationale for the textual differences?

First, while Ephesians 4:8c does not quote Psalm 68:18 verbatim, it alludes to it. ${ }^{73}$ The appearance in Ephesians 4:8 of $\delta$ ó $\mu \alpha$ ('gift'), a rare Pauline term that occurs in LXX-Psalms only in LXX-Psalm 67:19 (Eng. 68:18), suggests Paul had the verse in mind, especially since he typically used other 'gift' terminology, even as seen in the previous verse. ${ }^{74}$

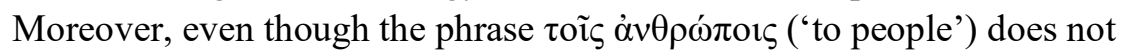
precisely match the Septuagint ('ُ $v \dot{\alpha} v \theta \rho \omega ́ \pi \omega$, 'by humanity') and syntactically differs as the indirect object instead of the object of a preposition, it likely alludes to Psalm 68:18 on account of its collocation with 'gifts' and the absence of $\alpha 0 \theta \rho \omega \pi \mathrm{s}$ from the rest of LXX-Psalm 67 (Eng. Ps. 68). Thus, in view of the rarity of $\delta$ ó $\mu \alpha$ in the Pauline corpus, its appearance only in LXX-Psalm 67:19, and the collocation of 'gifts'

71 Clinton E. Arnold, Power and Magic: The Concept of Power in Ephesians (Grand Rapids: Baker, 1992): 1-40.

72 For a similar approach to Paul's terminology of rulers, powers, etc., with particular reference to Deuteronomy 32, see Heiser, The Unseen Realm, 235-36.

73 Baugh, Ephesians, 331 rightly speaks of Eph. 4:8 as a 'free paraphrase' of Ps. 68:18.

$74 \Delta$ ó $\mu \alpha$ occurs twice in the Pauline corpus (Eph. 4:8; Phil. 4:17); $\delta \omega ́ \rho \varepsilon \alpha$ or $\chi \alpha \dot{\alpha} 1 \varsigma$ are much more often attested in the corpus. 
with 'people', Ephesians 4:8c likely continues the citation of Psalm $68: 18$, albeit with significant modifications.

Second, this allusion, in keeping with the psalmic context, means that Christ's gifts are intended for the construction and maintenance of the eschatological temple. Specifically, the use of the gifts in verses 11-16 identify the church as the eschatological temple and spiritually gifted people as the gifts themselves. Since the eschatological temple is different inasmuch as it is heavenly and 'made without hands', it is not surprising that the gifts are also, in a sense, heavenly and spiritual. ${ }^{75}$

Third, Paul modified Psalm 68:18 to account for Christ's identity and the way in which Christ fulfilled the psalm. As already observed, God is the pre-eminent Giver in Psalm 68, and he supplies all that his people need. Through his powerful word he gives redemption that enables his people to spread the good news of victory and elicits from them contributions for the temple. His reception of temple gifts from his people is predicated on his prior redemptive gifts to his people. Paul's identification of Christ as Giver to his people identifies Christ as YHWH, the one whose redemptive gifts are prior to and elicit temple gifts. As in the psalm, Christ's redemptive gifts enable his people to herald the good news of victory and to build up the church by means of his powerful word (Eph. 4:11). ${ }^{76}$ Declaring Christ to be the pre-eminent Giver was a fitting way for Paul to identify Christ as YHWH and to herald the fulfilment of the psalm's typological gift motif.

At the same time, since the gifts in Psalm 68:18 are from humans to God and are intended to construct and maintain the temple, then Paul's identification of Christ as the Giver of those gifts to God's people suggests that Christ is the chief Contributor to the eschatological temple. ${ }^{77}$ That the immediate recipient of Christ's gift is people instead of God does not indicate that in the psalm's redemptive-historical fulfilment there was no typological element corresponding to the original

75 Supporting this is the observation that the body metaphor in Eph. 4:11-16 develops the temple metaphor in Eph. 2:20-22, for in both texts the people of God are 'built up'

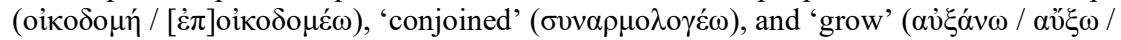

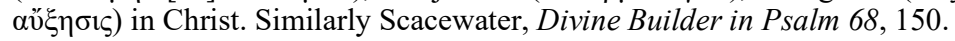

76 Michael Gese (Das Vermächtnis des Apostels, 185) suggests that the verb change in 4:8c owes to the combination of YHWH's word-gift in Ps. 68:11 with his ascension and triumph in Ps. 68:18. If he is right, then the result of YHWH's word-gift corresponds to the result of Christ's word-gift, for in both cases God's people 'herald good news' (Ps.

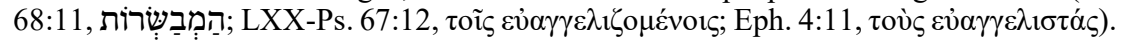
77 I am indebted to the excellent analysis on this point of Scacewater, Divine Builder in Psalm 68, 134-35. 
reception of gifts. ${ }^{78}$ Rather, given the nature in which the psalm was fulfilled through Christ, Paul was compelled to clarify the christological manner in which God receives gifts from humanity. Christ gave gifts to God's people through the Spirit so that God's people, in fulfilment of Psalm 68:18, can construct the eschatological temple in Christ. As the Representative of God's people, it is only through Christ that God's people are joined to and build up the eschatological temple, and he alone is its cornerstone (Eph. 2:20-22). This interpretation fits with the 'mystery' in Ephesians whereby the Jews and Gentiles are reconstituted as 'one new humanity' in Christ, in whom they together have access to God in his temple $(2: 15-18 ; 3: 6 ; 4: 24)$. Through his resurrection and ascension Christ represents the people of God; the temple contributions expected of God's people he fulfils in himself, and equips his people to do the same through the Spirit.

Thus, Ephesians 4:8c alludes to Psalm 68:18 but modifies it to account for Christ's identity and the psalm's redemptive-historical fulfilment in Christ. The shift from received to gave derived from Paul's Christology, in which Christ qua YHWH was the pre-eminent Giver of redemption, and in which Christ qua Representative was, in the revelation of the mystery, the chief Contributor of gifts for the eschatological temple. ${ }^{79}$ In this sense, as Todd Scacewater has aptly put it, 'Paul had no other way he could have quoted the psalm because his intention in citing it was to declare the fulfillment of the typological pattern, and that fulfillment had occurred in exactly the way he recorded it. ${ }^{\prime} 80$

78 E.g. Lunde and Dunne, 'Paul's Creative and Contextual Use', 114-15 argue the gifts in the psalm are tribute from God's subjugated enemies and therefore have no corresponding element in the psalm's fulfilment inasmuch as the spiritual powers Christ defeated give him no such tribute.

79 Identifying Christ qua YHWH is not here intended to flatten Paul's Trinitarian monotheism wherein Christ qua the divine Son is differentiated from the Father and the Spirit (e.g. 1 Cor. 8:6; Phil. 2:9-11). Nor is it intended to obscure Paul's typical way of speaking of Christ's mediatorial role as distinct from God. Rather, it is intended to show Paul's two-nature Christology in which Jesus, as God the Son incarnate, is fully divine and fully human and thus is fully qualified to accomplish the work of redemption. Thus, according to his divine nature, he is the Giver of redemption; according to his human nature, he is our Representative and Contributor of gifts to God on our behalf. For a good study of how Paul applies Old Testament YHwH texts to Christ, see David B. Capes, Old Testament Yahweh Texts in Paul's Christology (WUNT 2, 47; Tübingen: Mohr Siebeck, 1992; repr., Library of Early Christology; Waco, Texas: Baylor University Press, 2017). 80 Scacewater, Divine Builder in Psalm 68, 134. 


\section{Conclusion}

In Ephesians 4:8 Paul applied Psalm 68:18 to Christ in light of the psalm's typological expectation and its redemptive-historical fulfilment in Christ. Paul's apparent misapplication of the psalm is resolved by a proper recognition of the psalm's typological framework. The psalm's two halves mirror one another by means of correspondence and escalation. Israel's past story in the first half corresponds to and anticipates a greater story in the second. In Psalm 68:18 - a climactic moment in the psalm's narrative - YHWH's ascension, captives, and gifts correspond to and anticipate a greater ascension, captives, and gifts. The psalm's allusions to Exodus 15 and Judges 5 are not only retrospective but also prospective in that they anticipate an eschatological divine victory that resembles and surpasses prior divine victories.

Therefore, Paul's interpretation of Psalm 68:18 flows from his recognition of the psalm's typological framework. In light of both the psalm's eschatological orientation as well as the inauguration of the eschaton in Christ, Paul could interpret the psalm in no other way. The application of the psalm to Christ was the necessary entailment of the psalm's own eschatological character and the reality of God's victory accomplished in Christ. In this sense, Ephesians 4:8 is not a creative reworking of Psalm 68:18, nor does it import a meaning alien to the psalm's intent. Rather, it illustrates Paul's hermeneutical approach in which he interpreted the Old Testament Scriptures according to their own literary features and intent. His interpretation of the biblical text was formulated in light of the coming of Christ, yet it was grounded in the typological expectation of the biblical text itself. ${ }^{81}$

Recognising the typological framework of Psalm 68 not only absolves Paul from the charge of hermeneutical insensitivity but also explains the function of the citation in the pericope (Eph. 4:7-16). First, it explains the appearance of Psalm 68:18 as a Scriptural inference ( $\delta$ เó, v. 8): Christ's gift of grace in Ephesians 4:7 is the raison d'être of Psalm 68:18. Second, it explains the verbal shift from receiving to giving in Ephesians 4:8c. The textual modification allowed Paul to identify Christ as both YHWH - the pre-eminent Giver in the psalm - and the Representative of God's people responsible for the building of the eschatological temple. Third, the psalm's expectation that God's redemptive word-gifts would enable his people to herald divine victory and would elicit temple

81 Rightly Baugh, Ephesians, 329-31; Hodge, Ephesians, 216-17. 
contributions explains Paul's focus on Christ's gifts as the ministers of his word for the upbuilding of the church (4:11-16).

Finally, Paul's choice to quote Psalm 68:18 in particular owes to its place in the psalm and its collocation of the themes of divine victory and divine presence. With its emphasis on YHWH's ascension, triumph over his enemies, and the recognition of YHWH as king in his temple, Psalm 68:18 was the theological climax of Israel's story, and in light of the psalm's typological framework, it climactically expressed Israel's eschatological hope. Given Paul's emphases in Ephesians on Christ's victory and ascension over the principalities and powers as well as Christ's building of the eschatological temple in himself by means of his powerful word, Psalm 68:18 provided an apt window through which Paul could appropriate and apply the typological framework of the entire psalm to Christ and his people in Ephesians 4:7-16. 